\title{
Defective Intestinal Phosphate Absorption in Familial and Non-familial Hypophosphataemia
}

\author{
J. R. CONDON, ${ }^{*}$ M.B., B.SC., M.R.C.P. ; J. R. NASSIM, † F.R.C.P. ; A. RUTTER, $\ddagger$ B.SC.
}

\begin{abstract}
Cummary: With an oral phosphate tolerance test a primary defect in intestinal phosphate absorption was found in patients with untreated familial and non-familial hypophosphataemia. It is suggested that this plays a major part in the aetiology of rickets and osteomalacia in these disorders. Vitamin D was shown to have a beneficial effect on intestinal transport of phosphate, though defective absorption was not completely corrected. If intestinal phosphate absorption is normal, oral phosphate supplements will maintain normal plasma phosphate levels even in the presence of a pronounced renal phosphate leak.

In familial and non-familial hypophosphataemia the phosphate tolerance test may be a more sensitive index of genetic abnormality than a low plasma phosphate. It may be helpful in distinguishing several syndromes at present classified under non-familial hypophosphataemia, as well as assessing the response to treatment with vitamin $D$ and in investigating intestinal transport of phosphate.
\end{abstract}

\section{Introduction}

Familial hypophosphataemia (Winters et al., 1958) is one of a group of disorders characterized by a low plasma phosphate and commonly presenting as vitamin-D-resistant rickets in the child or osteomalacia in the adult. Transmission is dominant and sex-linked, the affected gene being situated on the $\mathrm{X}$ chromosome. In this disorder there is no evidence of dietary deficiency of vitamin $\mathrm{D}$, steatorrhoea, chronic renal failure, renal tubular acidosis, or renal tubular defect as found in the Fanconi and related syndromes. Non-familial hypophosphataemia is a similar disorder, but there is no family history of rickets and osteomalacia or any evidence of a low plasma phosphate in parents of affected individuals.

Though undoubtedly there is a renal phosphate leak in familial and non-familial hypophosphataemia, the exact mechanism of the low plasma phosphate is uncertain. One possible explanation is a primary defect in renal tubular reabsorption of phosphate (Robertson et al., 1942; Dent, 1952; Fanconi and Girardet, 1952). Albright et al. (1946), however, thought that defective renal tubular reabsorption of phosphate was due to hyperparathyroidism which developed secondarily to a primary defect of intestinal absorption of calcium, malabsorption of calcium being the result of a "resistance" to vitamin D. There is, however, no clinical evidence of excess parathyroid activity in most patients with familial and nonfamilial hypophosphataemia.

A third possibility is defective transport of phosphate across the intestinal mucosa. A primary disorder of intestinal phosphate absorption has, however, never been conclusively shown in hypophosphataemic rickets or osteomalacia, though there is a raised faecal phosphate (Albright et al., 1937; Robertson et al., 1942; Fanconi and Girardet, 1952; Jackson et al., 1958; Nordin and Smith, 1967). The latter is, however,

* Senior Medical Registrar, St. George's Hospital, London S.W.1.

† Consultant Physician, St. George's Hospital, London S.W.1, and Royal National Orthopaedic Hospital, London W.1.

¥ Department of Biochemistry, Royal National Orthopaedic Hospital, accompanied by a raised faecal calcium (Albright et al., 1937; Freeman and Dunsky, 1950), and it is generally accepted that any apparent defect in absorption of phosphate from the gut is secondary to defective absorption of calcium.

In our study intestinal absorption of phosphate in familial and non-familial hypophosphataemia was assessed. The role of defective intestinal absorption of phosphate in the pathogenesis of rickets and osteomalacia is discussed. The relative importance of intestinal absorption and renal loss of phosphate was also studied in three patients who had normal intestinal absorption but defective renal tubular reabsorption of phosphate. It is suggested that the phosphate tolerance test may be a more sensitive index of genetic abnormality than a low plasma phosphate, and the test may be of use in investigating factors influencing intestinal absorption of phosphate.

\section{Subjects}

Three groups of subjects were investigated.

Group 1.-Five adults and Case 6 , a child (weight $30 \mathrm{~kg}$.), with familial or non-familial hypophosphataemia. These patients had either never received any treatment with vitamin $D$ and phosphate supplements or had stopped treatment more than three years before the present study.

Group 2.-Eight adults and a child (Case 6) with either familial or non-familial hypophosphataemic rickets or osteomalacia who were each receiving between 40,000 and 140,000 units of calciferol daily. In all instances phosphate supplements had been stopped more than three days before investigation.

Group 3.-Eight normal adults and one normal child aged 9 years (weight $32 \mathrm{~kg}$.).

Case 6 is included in groups 1 and 2 because phosphate tolerance tests were performed before and during treatment of his rickets with vitamin $\mathrm{D}$.

Three additional patients were investigated. One (Case 24) had generalized amino-aciduria in addition to hypophosphataemia and defective renal tubular reabsorption of phosphate. She had rickets when 6 years old, but grew to a normal height (5ft. 5in.) after treatment with vitamin $D$ and phosphate supplements. The two other patients (Cases 25 and 26) had hypercalciuria in addition to hypophosphataemia and defective renal tubular reabsorption of phosphate, but neither had any evidence of rickets or osteomalacia.

Eleven of the patients in groups 1 and 2 had a family history of rickets or proved osteomalacia in one parent. The other three (Cases 1, 11, and 14) had no family history of rickets or osteomalacia, and the fasting plasma phosphate values of their parents fell within the normal range. The average weight of the control subjects was $13.2 \mathrm{~kg}$. more than that of the patients in groups 1 and 2.

\section{Methods}

All subjects fasted overnight and received nothing to eat or drink next mcining. Immediately before beginning the tolerance test the ntients urinated and the urine was discarded. Then $6.9 \mathrm{~g}$. of sodium phosphate powder ( $\equiv 1.5 \mathrm{~g}$. of phosphorus) dissolved in $200 \mathrm{ml}$. of water was administered 
orally over two minutes. This was followed by $15 \mathrm{ml}$. of water in order to relieve the bitter taste caused by the sodium phosphate solution. Venous blood samples collected in heparin were withdrawn two minutes before and 30,60, 90, 150 , and 210 minutes after administration of sodium phosphate solution. The patient urinated at the end of the test; the urine volume was measured, the specimen being kept for analysis.

Plasma and urinary inorganic phosphate was estimated on both blood and urine samples with the Technicon AutoAnalyzer Method N4b (Technicon AutoAnalyzer Handbook).

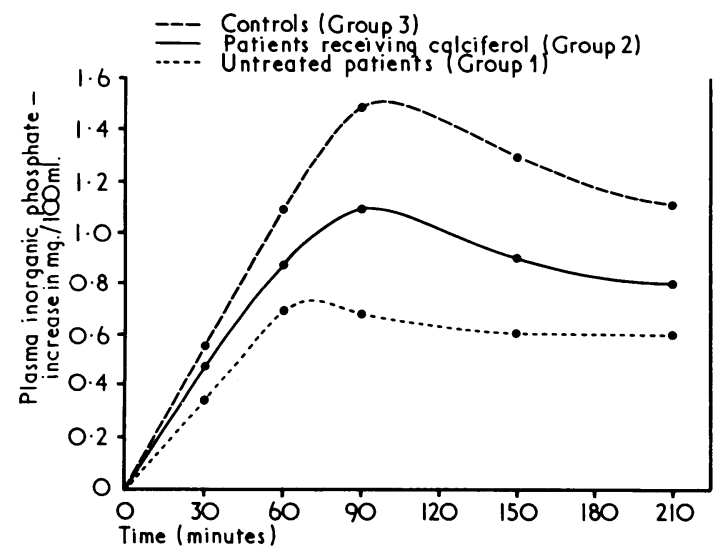

Fig. 1.- Average rise of plasma phosphate at time intervals following ingestion of $6.9 \mathrm{~g}$. of sodium phosphate dissolved in $200 \mathrm{ml}$. of water is recorded in adult patients with familial and non-familial hypophosphataemia.

Calcium analysis was performed by atomic absorption spectrophotometry (Unicam S.P. 90) with the Unicam atomic absorption method $\mathrm{Ca} 2$ (Unicam publications).

Maximum renal tubular reabsorption of phosphate was measured in Case 25 by the method of Anderson (1965) and in Case 26 by the method of Bijvoet et al. (1969). Tubular reabsorption of phosphate was assessed from plasma phosphate and the concomitant measurement of the ratio of phosphate excretion rate to glomerular filtration rate ( $\mathrm{Tm} /$ G.F.R.). This ratio was obtained from measurements of phosphate and creatinine concentrations in plasma and in an untimed specimen of urine from the fasting patient. Tm/G.F.R. was predicted from these data by means of a nomogram.

Informed consent was obtained from the patients for all procedures carried out.

\section{Results}

The plasma phosphate values in groups 1,2 , and 3 and the three additional patients (Cases 24, 25, and 26) are shown in the Table. Total urinary phosphate excretion during the tolerance tests is also recorded. All patients with familial and nonfamilial hypophosphataemia not being treated with vitamin D (group 1) had flat tolerance curves compared to control subjects (group 3) (Fig. 1).

Maximum rise in plasma phosphate in oontrol subjects was $1.57 \pm 0.46 \mathrm{mg} . / 100 \mathrm{ml}$. The maximum rise in patients with familial hypophosphataemia not receiving vitamin $D$ was $0.78 \pm 0.13 \mathrm{mg} . / 100 \mathrm{ml}$. There is a significant difference between these two groups. Patients with hypophosphataemia receiving vitamin $\mathbf{D}$ (group 2) had phosphate tolerance curves which lay about midway between those of subjects in groups 1 and 3. The mean maximum rise in plasma phosphate in group 2 patients was $1.07 \pm 0.46 \mathrm{mg} . / 100 \mathrm{ml}$. In only two of these patients (Cases 13 and 14) did the maximum rise in
Urine Phosphate (mg.) and Plasma Phosphate Values ( $\mathrm{mg} .100 \mathrm{ml}$.) after Ingestion of $6.9 \mathrm{~g}$. of Sodium Phosphate Dissolved in $200 \mathrm{ml}$. of Water

\begin{tabular}{|c|c|c|c|c|c|c|}
\hline \multirow{2}{*}{ Case No. } & \multicolumn{6}{|c|}{ Time (Minutes) } \\
\hline & 0 & 30 & 60 & 90 & 150 & 210 \\
\hline
\end{tabular}

\begin{tabular}{c|l|l|l|l|l|l|l}
\multicolumn{8}{l}{ Group 1. Untreated Patients } \\
\hline 1 & 1.1 & 1.4 & 2.0 & 1.7 & 1.9 & 2.1 & 55 \\
2 & 2.6 & 2.7 & 3.4 & 3.4 & 3.4 & 3.4 & 110 \\
3 & 1.8 & 2.1 & 2.4 & 2.5 & 2.5 & 2.5 & 72 \\
4 & 1.8 & 2.1 & 2.3 & 2.5 & 2.2 & 2.1 & 249 \\
5 & 2.1 & 2.6 & 2.8 & 2.7 & 2.5 & 2.4 & 106 \\
\hline Average & 1.88 & 2.18 & 2.58 & 2.56 & 2.50 & 2.50 & 118 \\
\hline 6 & 2.1 & 2.7 & 3.3 & 3.4 & 3.2 & 3.0 & 208
\end{tabular}

\begin{tabular}{c|l|l|l|l|l|l|r}
\multicolumn{8}{c}{ Group 2. Patients Receiving Vitamin D Therapy } \\
\hline 7 & 2.0 & 2.3 & 2.4 & 2.8 & 2.5 & 2.5 & 90 \\
8 & 1.7 & 1.9 & 2.8 & 2.5 & 2.5 & 2.5 & 162 \\
9 & 1.5 & 2.0 & 2.3 & 2.4 & 2.4 & 2.4 & 200 \\
10 & 0.9 & 1.6 & 1.7 & 1.9 & 1.8 & 1.8 & 95 \\
11 & 1.3 & 1.6 & 2.0 & 2.3 & 2.3 & 2.1 & 88 \\
12 & 1.7 & 2.3 & 2.5 & 2.7 & 2.8 & 2.5 & 106 \\
13 & 1.2 & 1.6 & 2.0 & 2.4 & 2.3 & 2.3 & 225 \\
14 & 2.3 & 3.0 & 3.7 & 3.8 & 3.1 & 3.0 & 179 \\
\hline Average & 1.57 & 2.04 & 2.42 & 2.60 & 2.46 & 2.39 & 143 \\
\hline 6 & 2.1 & 2.7 & 3.4 & 3.7 & 3.7 & 3.5 & 370 \\
\hline
\end{tabular}

\begin{tabular}{|c|c|c|c|c|c|c|c|}
\hline $\begin{array}{l}15 \\
16 \\
17 \\
18 \\
19 \\
20 \\
21 \\
22\end{array}$ & $\begin{array}{l}3.5 \\
3.2 \\
3.2 \\
4.3 \\
3.5 \\
3.7 \\
3.0 \\
3.0\end{array}$ & $\begin{array}{l}4.4 \\
4.0 \\
3.6 \\
5.0 \\
3.8 \\
4.1 \\
3.2 \\
3.4\end{array}$ & $\begin{array}{l}4.6 \\
4.6 \\
4.3 \\
5.5 \\
4.4 \\
4.6 \\
4.0 \\
3.9\end{array}$ & $\begin{array}{l}5 \cdot 0 \\
5 \cdot 0 \\
4 \cdot 8 \\
5.9 \\
4 \cdot 6 \\
4.9 \\
4 \cdot 6 \\
4 \cdot 4\end{array}$ & $\begin{array}{l}4.2 \\
4.5 \\
4.6 \\
5.4 \\
4.8 \\
5.0 \\
4.7 \\
4.9\end{array}$ & $\begin{array}{l}3 \cdot 8 \\
4 \cdot 1 \\
4 \cdot 6 \\
5 \cdot 2 \\
4 \cdot 9 \\
4 \cdot 8 \\
4 \cdot 3 \\
4 \cdot 8\end{array}$ & $\begin{array}{l}270 \\
265 \\
291 \\
351 \\
284 \\
208 \\
336 \\
246\end{array}$ \\
\hline Average & 3.42 & 3.94 & 4.49 & 4.90 & $4 \cdot 76$ & 4.56 & 281 \\
\hline 23 & 3.4 & $4 \cdot 6$ & $5 \cdot 7$ & 6.6 & $7 \cdot 0$ & $5 \cdot 6$ & 394 \\
\hline
\end{tabular}

\begin{tabular}{l|l|l|l|l|l|l|l}
\multicolumn{8}{c}{ Additional Patients Investigated } \\
\hline 24 & 1.2 & 1.6 & 1.8 & $2 \cdot 1$ & 2.3 & 2.6 & 133 \\
25 & 1.5 & 2.2 & 3.8 & 3.8 & 3.7 & 3.7 & 162 \\
26 & 1.8 & 2.6 & 2.7 & 2.8 & 3.2 & 3.0 & 142 \\
\hline
\end{tabular}

plasma phosphate fall within the range of the control subjects, and it is of interest that both these subjects were receiving over 100,000 units of vitamin D per day.

Urine phosphate measured over the duration of the test was higher in controls than in hypophosphataemic patients and presumably represents the higher plasma phosphate levels attained by the controls following phosphate ingestion. Though a renal phosphate leak was present in all hypophosphataemic patients studied, excretion of phosphate in the urine over the duration of the test was about twice as much in control subjects as in untreated and treated patients. It is therefore obvious that a renal leak cannot account for the flat phosphate tolerance curves found in patients in groups 1 and 2.

The three additional patients investigated all had normal phosphate tolerance curves. Despite increased phosphaturia Case 24 maintained normal plasma phosphate levels when treated for rickets with vitamin $\mathrm{D}$ and oral phosphate. Phosphate supplements alone will at the present time maintain her plasma phosphate level within the normal range. This finding prompted us to investigate two patients (Cases 25 and 26) who had hypercalciuria in addition to hypophosphataemia and defective renal tubular reabsorption of phosphate. Case 25 had a TmP of $90 \mu$ moles/min. (normal $165 \pm 25 \mu$ moles $/ \mathrm{min}$; Woolf, 1966). Case 26 had a Tm/G.F.R. of $24 \mathrm{mg}$./litre. Both these patients normally have low plasma phosphate values but maintain normal plasma phosphate levels when supplements of phosphate alone are ingested every six hours. Phosphate tolerance curves before and during treatment with 
calciferol in a 9-year-old child (Case 6) with familial hypophosphataemic rickets are shown in Fig. 2; the tolerance curve of a normal control (Case 23) of the same age is also shown. After treatment with $2 \mathrm{mg}$. of calciferol daily for two weeks no improvement occurred in the phosphate tolerance test. Two months later the phosphate tolerance test had improved considerably (Fig. 2).

Plasma phosphate data from Cases 6 and 23 were not included in the averages of groups 1,2 , and 3 because the

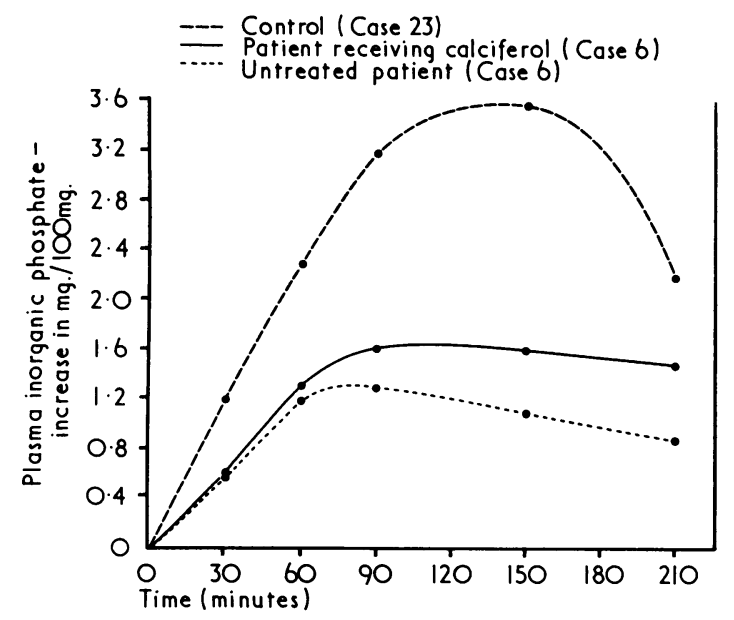

FIG. 2.-Rise in plasma phosphate at time intervals following ingestion of $6.9 \mathrm{~g}$. of sodium phosphate dissolved in $200 \mathrm{ml}$. of water recorded in a child (Case 6) with familial hypophosphataemic rickets before and a child (Case 6) with familial hypophosphataemic rickets before and
during treatment with calciferol, and in a normal control child (Case 23).

oral loading dose of phosphate was not adjusted for body weight in these children. For this reason there was a relatively large maximum rise in plasma phosphate of 1.3 and $1.6 \mathrm{mg} . / 100 \mathrm{ml}$. in Case 24 and $3.6 \mathrm{mg} . / 100 \mathrm{ml}$. in Case 23.

\section{Discussion}

It is well known that there is defective renal tubular reabsorption of phosphate in familial and non-familial hypophosphataemia, and a high faecal calcium and phosphorus have been found in these disorders. Defective intestinal absorption of phosphate is generally thought to be secondary to malabsorption of calcium, especially in view of the fact that vitamin $D$, which is known to act mainly on calcium transport mechanisms, increases intestinal absorption of both calcium and phosphorus.

We have shown that following ingestion of a solution of sodium phosphate a significant difference in the maximum rise in plasma phosphate occurs in normal subjects (group 3) and in patients with familial hypophosphataemia not receiving vitamin D (group 1). These findings probably are due to a primary defect in intestinal absorption of phosphate, since inorganic phosphate is more readily absorbed from the gut than phosphate "bound" in food (Parfitt et al., 1964; Nassim and Higgins, 1965). The other explanation for the flat tolerance curves observed in patients in group 1 is that there is a more rapid deposition of phosphate in their bones and soft tissues than in control subjects. This explanation is not favoured, as only one of the patients from group 1 was suffering from active bone disease, and a calcium phosphorus balance study in this individual showed that he was in zero balance.

Possibly defective intestinal absorption of phosphate in familial and non-familial hypophosphataemia plays a major part in the aetiology of rickets and osteomalacia in these disorders, since, in man, binding of phosphate in the gut by prolonged ingestion of non-absorbable alkali results in rickets or osteomalacia (Lotz et al., 1964). Likewise rickets can be produced in rats by oral administration of metallic salts which form insoluble phosphates in the gut (Lehnerdt, 1910); Waltner, 1927; Rominger, et al., 1930; Mouriquand et al., 1931). The rickets produced is, however, prevented if more phosphate than can be precipitated by the ingested metal is added to the rats' diet.

Defective intestinal phosphate absorption in familial and non-familial hypophosphataemic rickets and osteomalacia accounts for several previously inexplicable facts. It explains why attempts to treat patients with oral phosphate alone have usually not succeeded (Frame et al., 1963; Rose, 1964; West et al., 1964) despite the fact that intravenous phosphate rapidly heals the bone lesions (Fraser et al., 1957, 1958). Bone healing, however, has occasionally occurred in patients after only two to three months of oral phosphate therapy (Nagant de Deuxchaisnes and Krane, 1965), and these patients may well correspond to our patient with generalized aminoaciduria, hypophosphataemic rickets, and defective renal tubular reabsorption of phosphate. She grew to a normal height and maintained normal plasma phosphate levels despite increased phosphaturia following treatment with oral phosphate and vitamin $\mathrm{D}$ for rickets. She has a normal phosphate tolerance test and can maintain normal plasma phosphate levels when given oral phosphate supplements alone. Probably those patients capable of absorbing "adequate" quantities of phosphate from the intestinal tract are the ones who would show a therapeutic response to ingestion of oral phosphate alone.

Though attempts to treat patients with oral phosphate alone have usually been unsuccessful, this is not true of oral phosphate supplements in addition to vitamin $\mathrm{D}$ therapy. With this combination there is more rapid mineralization of bone (Frame et al., 1961; Holland and West, 1962), and administration of phosphate supplements may allow a reduction of vitamin D dosage to less than 100,000 units per day, thus resulting in a decreased incidence of toxic side-effects (Wilson et al., 1965).

Vitamin $\mathrm{D}$ has never been conclusively shown to increase renal tubular reabsorption of phosphate in familial and nonfamilial hypophosphataemic rickets or osteomalacia, though a rise in plasma phosphate has often been reported. We have shown that some patients suffering from hypophosphataemic rickets or osteomalacia who are receiving 40,000-140,000 units of calciferol per day had increased absorption of phosphate from the gut when compared to non-treated patients. In Cases 8,10,11,12, 13, and 14 the maximum rise in plasma phosphate differed significantly from that of untreated patients in group 1. Increased intestinal absorption of phosphate may therefore account for at least part of the beneficial effect of vitamin D in familial and non-familial hypophosphataemic rickets and osteomalacia.

In the three hypophosphataemic patients (Cases 24, 25, and 26) with normal phosphate tolerance tests, but with defective renal tubular reabsorption of phosphate, normal plasma phosphate levels were attained and maintained when oral phosphate supplements alone ( $\equiv 500 \mathrm{mg}$. of phosphorus) were administered at six-hourly intervals. Thus even when a pronounced renal phosphate leak is present normal plasma phosphate can be maintained with oral phosphate supplements if intestinal phosphate absorption is normal. In contrast, normal plasma phosphate values could not be attained with oral phosphate, with or without vitamin $\mathrm{D}$, in any of the patients with familial or non-familial hypophosphataemia except Case 14. It is suggested that the reason for this difference is the presence of defective intestinal absorption of phosphate in the patients with familial and non-familial hypophosphataemia, who of course, also have a renal phosphate leak. In view of these findings possible ways of improving intestinal phosphate absorption deserve further investigation. 
We gratefully acknowledge advice given by Professor C. E. Dent in the preparation of this paper.

\section{REFERENCES}

Albright F., Burnett, C. H., Parson, W., Reifenstein, E. C., and Roos, A. (1946). Medicine, 25, 399.

Albright, F., Butler, A. M., and Bloomberg, E. I. (1937). American fournal of Diseases of Children, 54, 529

Anderson, J. (1965). Fournal of Physiology, 130, 268.

Bijvoet, O. L. M., Morgan, D. B., and Fourman, P. (1969). Clinica Chemica Acta, 26, 15

Dent, C. E. (1952). Fournal of Bone and foint Surgery, 34B, 266.

Fanconi, G., and Girardet, P. (1952). Helvetica Paediatrica Acta, 7, 14.

Freeman, S., and Dunsky, I. (1950). American Fournal of Diseases of

Children, 79, 409.
Frame, B., Smith, R. W., jun., Fleming, J. L., and Manson, G. (1963). American fournal of Diseases of Children, 106, 147

Frame, B., Smith, R. W., and Wilson, E. W. (1961). Henry Ford Hospital Medical Bulletin, $9,548$.

Fraser, D., Jaco, N. T., Yendt, E. R., Munn, J. D., and Liu, E. (1957). American fournal of Diseases of Children, 93, 84

Fraser, D., et al. (1958). American fournal of Diseases of Children, 96, 460.

Holland, N. H., and West, C. D. (1962). Report of the Society for Paediatric Research, p. 117.

Jackson, W. P. U., Dowdle, E., and Linder, G. C. (1958). British Medical fournal, 1, 1269.
Lehnerdt, F. (1910). Beiträge zur pathologischen Anatomie und zur allgemeinen Pathologie, 47, 215

Lotz, M., Ney, R., and Bartter, F. C. (1964). Transactions of the Associations of American Physicians, 77, 281.

Mouriquand, G., Leulier, A., Bernheim, M., and Weill (1931). Presse Médicale, 39, 769.

Nagant de Deuxchaisnes, C., and Krane, S. M. (1965). Fournal of Clinical Investigation, 44, 1078.

Nassim, J. R., and Higgins, B. A. (1965). British Medical fournal, 1, 675.

Nordin, B. E. C., and Smith, D. A. (1967). In L'Ostéomalacie, ed. D. J. Hioco, p. 379. Paris, Masson. Parfitt, A. M., Higgins, B. A., Nassim, J R., Collins, J. A., and Hilb,
A. (1964). Clinical Science, 27, 463.

Robertson, B. R., Harris, R. C., and McCune, D. J. (1942). American

fournal of Diseases of Children, 64, 948
Rominger, E., Meyer, H., and Bomskov, C. (1930). Zeitschrift für die gesamte experimentelle Medizin, 73, 343.

Rose, G. A. (1964). British Medical fournal, 2, 857.

Rose, G. A. (1964). British Medical fournal, 2, 857.
Waltner, K. (1927). Biochemische Zeitschrift, 188, 381.

West, C. D., Blanton, J. C., Silverman, F. N., and Holland, N. H. (1964). Fournal of Pediatrics, 64, 469.

Wilson, D. R., York, S. E., Jaworski, Z. F., and Yendt, E. R. (1965). Medicine, 44, 99.

Winters, R. W., Graham, J. B., Williams, T. F., McFalls, V. W., and Burnett, C. H. (1958). Medicine 37, 97.

Woolf, L. I. (1966). Renal Tubular Dysfunction, p. 100. Springfield, Illinois, Thomas.

\title{
Effect of Potassium Supplements on the Exchangeable Potassium in Chronic Heart Disease
}

\author{
R. J. WHITE,* M.B., M.R.C.P.
}

British Medical fournal, 1970, 3, 141-142

\begin{abstract}
Ummary: A study of the effect of additional oral potassium on the low body potassium of seven patients with severe valvular heart disease showed that the potassium supplements were retained. After one month's treatment the exchangeable potassium was significantly increased, but the predicted value was not reached in any of the patients. There was no significant change in plasma potassium. These results suggest that it is of benefit to increase the dose of oral potassium for at least one month preoperatively in patients undergoing cardiac surgery.
\end{abstract}

\section{Introduction}

Patients with severe heart disease are frequently depleted of potassium. It is often assumed that the intracellular potassium concentration is reduced, and that this may give rise to serious ill-effects such as cardiac arrhythmias. In some centres it is routine to increase the dose of oral potassium preoperatively with the intention of increasing the body potassium. The efficacy of this treatment in producing a rise in the cellular potassium is, however, not known. The effect of potassium supplements on the exchangeable potassium of patients with severe valvular heart disease has been studied. Since about $95 \%$ of the exchangeable potassium is intracellular, this measurement provides a good index of cellular potassium.

The findings suggest that the reduction of exchangeable potassium is at least partially corrected by oral potassium supplements, but a distinction cannot be made between an increase in intracellular potassium concentration and a movement of water together with potassium into the cells.

\section{Methods}

Seven patients with severe valvular heart disease were studied (Table I). They consented to the study after full explanation of the nature of the investigation and the procedures

*Medical Registrar, St. Bartholomew's Hospital, London E.C.1.
TABLE I.-Clinical Data

\begin{tabular}{|c|c|c|c|c|c|}
\hline Case No. & Age & Sex & $\begin{array}{c}\text { Height } \\
(\mathrm{cm} .)\end{array}$ & Diagnosis & Drug Therapy (Daily Dose) \\
\hline 1 & 27 & F. & 166 & M.V.D. & $\begin{array}{l}\text { Frusemide } 40 \mathrm{mg} \text {. Digoxin } 0.25 \mathrm{mg} . \\
\text { Slow-K } 600 \mathrm{mg} \text {. }\end{array}$ \\
\hline 2 & 50 & M. & 174 & A.V.D. & $\begin{array}{l}\text { Ethacrynic acid } 100 \mathrm{mg} \text {. Digoxin } 0.5 \\
\text { mg. Aldactone A } 100 \mathrm{mg} \text {. Slow-K } 1,800 \\
\mathrm{mg} \text {. }\end{array}$ \\
\hline $\begin{array}{l}3 \\
4\end{array}$ & $\begin{array}{l}24 \\
61\end{array}$ & F. & $\begin{array}{l}156 \\
159\end{array}$ & $\begin{array}{l}\text { A.V.D. } \\
\text { A.V.D. }\end{array}$ & $\begin{array}{l}\text { Navidrex K } 2 \text { tablets. Digoxin } 0.5 \mathrm{mg} \text {. } \\
\text { Frusemide } 40 \mathrm{mg} \text {. Digoxin } 0.25 \mathrm{mg} \text {. } \\
\text { Slow-K } 600 \mathrm{mg} \text {. }\end{array}$ \\
\hline 5 & 50 & F. & 152 & A.V.D. & $\begin{array}{l}\text { Bendrofluazide io mg. Digoxin } 0.25 \mathrm{mg} \text {. } \\
\text { Slow-K } 600 \mathrm{mg} \text {. }\end{array}$ \\
\hline $\begin{array}{l}6 \\
7\end{array}$ & $\begin{array}{l}42 \\
27\end{array}$ & $\begin{array}{l}\text { F. } \\
\text { F. }\end{array}$ & $\begin{array}{l}158 \\
160\end{array}$ & $\begin{array}{l}\text { M.V.D. } \\
\text { M.V.D. }\end{array}$ & $\begin{array}{l}\text { Digoxin } 0.25 \mathrm{mg} \text {. } \\
\text { Navidrex } \mathrm{K} \text { two tablets. Digoxin } 0.5 \mathrm{mg} .\end{array}$ \\
\hline
\end{tabular}

M.V.D. = Mitral valve disease. A.V.D. = Aortic valve disease.

involved. All except Case 6 had suffered from episodes of left ventricular or congestive heart failure, and were receiving diuretics together with potassium supplements. They were, however, free of oedema at the time of study and were being prepared for open-heart surgery. All were on digoxin.

The patients were given additional potassium in the form of Slow-K for one month. A daily supplement of $48 \mathrm{mEq}$ of potassium was attempted, but this dose was not given to Case 2 because the oral potassium dose was already large. This patient therefore received $24 \mathrm{mEq}$ daily. Case 4 was started on $48 \mathrm{mEq}$, but this was reduced the next day to $32 \mathrm{mEq}$ because of nausea. During the period of investigation the existing drug therapy was continued unchanged.

Measurements of plasma sodium and potassium and exchangeable potassium were made the day before oral potassium was increased, and were repeated after one month of treatment. Two measurements of total body water also were made in four of the patients. Exchangeable potassium was measured by isotope dilution, with ${ }^{42} \mathrm{~K} ; 100 \mu \mathrm{Ci}$ was injected intravenously and urine samples were collected 22-24 hours and 24-26 hours after the dose. The mean of the result from the two urine samples was taken. Normal values were predicted from the age, sex, and height of the patient, the regressions loge $\mathrm{K}^{\mathrm{e}}$ on loge height, derived by Flear et al. 